\section{JMLE \\ JOURNAL OF MEDIA LITERACY EDUCATION}

\title{
Connect the dots
}

\section{Oopen access}

Voices from the Field - Peerreviewed article

Citation: McDonough, E. (2021). Connect the dots. Journal of Media Literacy Education, 13(3), 141-144. https://doi.org/10.23860/JMLE-202113-3-13

\section{Corresponding Author:}

Edward McDonough

mcdonoughe@cantonma.org

Copyright: () 2021 Author(s). This is an open access, peer-reviewed article published by Bepress and distributed under the terms of the Creative Commons Attribution License, which permits unrestricted use, distribution, and reproduction in any medium, provided the original author and source are credited. JMLE is the official journal of NAMLE.

Received: October 26, 2021

Accepted: December 2, 2021

Published: December 29, 2021

Data Availability Statement: All relevant data are within the paper and its Supporting Information files.

Competing Interests: The Author(s) declare(s) no conflict of interest.

\section{$\underline{\text { Editorial Board }}$}

\author{
Edward McDonough \\ Canton High School, USA
}

\begin{abstract}
During the dawn of the Covid Pandemic our isolation was a depressant. As teachers we were struggling with how to teach, as the popular saying explains, in an environment "that was like building an airplane as we were learning how to fly it." As a teacher in practice, Virtually Viral Hangouts became my antidepressant. This daily online community of educators gave me the skills to teach more effectively during the pandemic and beyond. The experience taught me how to seek and forge connections with students and cyber colleagues; how to carve out a cyber environment of psychological safety to be more inclusive; how to value learning by doing. The impact of sharing ideas with others resulted in a published "Online Learning Guide" that was translated into Portuguese and adapted for use by educators in Brazil.
\end{abstract}

Keywords: media literacy, online community, community of practice, coronavirus.

\section{Journal of Media Literacy Education}

THE OFFICIAL PUBLICATION OF THE

National Association for Media Literacy Education (NAMLE)

Online at www.jmle.org 


\section{INTRODUCTION}

When I was a kid, it was an era of spectacular children's television series. Back then, Zoom ${ }^{1}$ (PBS circa 1972) was not a meeting online, it was a group of kids with various talents, dancing, playing, and learning from each other._That vibe is in essence what Virtual Viral Hangouts (VVH) became for me and a group of educators this past spring, during the dawn of the pandemic.

We were basically COVID refugees enduring the stress of quarantining. While sheltering in place, most of us were teaching online for the first time. We were looking at a screen of names, rather than expressive faces, which was taking its toll on our psyches. The walls of our homes were closing in upon us. Otherwise brilliant and experienced educators were having the rug pulled out from under us. It was as if we were first year teachers again, frequently failing forward rather than being in control of our classrooms. Add that to the stress of being home alone, I was becoming depressed.

VVH became my antidepressant. The Covid reality of working from home was in some ways quite oppressive. My email box, which was once dutifully cleared by the end of each day, had become clogged with thousands of messages. The ping, ping, ping of emails was overwhelming, as annoying as a dripping faucet preventing sleep. Ping... a student has entered my zoom meeting. Ping... a notification of an assignment being turned in late to Google classroom. Ping... a question of clarification making me wonder if I had ever been a competent teacher.

Add to this the unrelenting rising tide of spam. It included a plague of politicians requesting support, in a brutally divisive presidential campaign year. I was simply drowning in email with an inbox that never was cleared, barley, able to tread water in that electronic sea. Miraculously and magically, my flailing arms found $\mathrm{VVH}$, which became a life ring of support.

Like a wallflower, I slid into my first VVH Zoom meeting with a goal to lurk in the background and passively observe. The host, Renee Hobbs, would have none of it. That was when I learned my first lesson of online teaching. Unlike my own Zoom meetings, where I seemed to be just talking to myself, Hobbs was a master conductor, guiding, us to see the connections among us, with the intention of building a learning community.

\section{Building connections}

It all started with the sense of connectivity, which are the seeds to sow in order to grow an orchard. Renee Hobbs chaired most meetings, gently inviting each new member to introduce themselves. What became the fertilizer to make it grow was what was done next. Part of the opening ritual of VVH was introductions; these were not the usual throw away lines, but instead a foundation to form social relationships. Renee would sometimes ask who among us has something in common with our new member? When I introduced myself, Renee would ask for someone who had a connection to my work as a high school video production teacher, and someone would volunteer, noting, for example, that they also teach in a high school. It was refreshing to meet people who were intent on noticing our similarities, not our differences. We met others who shared some of the exact struggles at work that we faced ourselves, in our own jobs. One person I was introduced to was Lauren McClanahan, a filmmaker and professor of secondary education who lives in Bellingham. Wow, I thought, Bellingham is just 25 miles away from me, why haven't I met McClanahan before? Well, that was because McClanahan was in Bellingham, Washington, not Bellingham, Massachusetts! At VVH, the participants were not just regional or national, but international, with educators and creative people from all over the U.S., as well as Canada, Mexico, Brazil, Costa Rica, Israel, Austria, Romania, and many more places.

Educators sadly live in departmentalized silos. Teaching video production, I am isolated even more, a singleton amongst a sea of subject-centered collaborators. Sure, I am lucky to be in a department of other talented art educators, but none of them teach broadcast media. Few teach digitally. VVH gave me the opportunity to connect, not just with others in the video production media field, but folks who had incredible insights into the world of digital online teaching. Like the Zoom kids' TV series of my childhood, VVH became a playground and laboratory, a place to experiment with the many ways learning can happen online.

\section{Mutual Inspiration}

There were so many talented educators who participated in VVH, and each session was hosted by different members. One day McClanahan shared with

\footnotetext{
${ }^{1}$ https://youtu.be/F7gzHLKT5g4
} 
our group a mini-documentary titled Bellingham Quarantine 2020 (McClanahan, 2020) that she had made on how Covid-19 impacted her community. While I fancy myself as a filmmaker, most of my time is absorbed teaching.

As with the proverbial "cobbler's kid having no shoes, "I have a ton of personal projects in the pipeline that often never get made due to a lack of time. When I shared that perspective with Lauren, she lit a fire under me. McClanahan did not just implore me to take better self-care, but also she fed my soul as a creative. That challenge was accepted, and as a result, I crafted something that would have otherwise been destined to an unfulfilled life in the digital graveyard of good ideas. Instead, Cherish the Moments - 2020 Hindsight (McDonough, 2020), was born: a short video I created to embrace the moments we all previously took for granted.

For one of the VVH meetings, I recruited media teacher and colleague Don Goble to lead a session. He is an instructor at Ladue Horton Watkins High School in St. Louis, Missouri. Don has had many students develop professional careers in the broadcasting industry. During the COVID pandemic, he had the genius idea of interviewing his former students. The result is Media Makers (Goble, 2020), a wonderful index of folks dispensing advice and their experiences working in jobs ranging from news, podcasting, education, film, music and entertainment. This resource became a go- to assignment for me during unexpected snow days. The index gave students a choice of topics for asynchronous learning. I had simply give them the list and they completed a 3-2-1 reflection protocol. This simple protocol promotes active viewing comprehension. After viewing, students identified three things they learned, two things they found most interesting, and one thing they wanted to learn more about. It was the connections, like the one I had made with Don, that made VVH a bounty of life rings all throughout the storm.

The VVH community made each other better through our active participation. We pushed each other to be better people and educators. While many of us took an online course or two, few of us had ever taught one... until COVID. Then we all scrambled to develop effective online content and learn new delivery platforms, from the mechanics of online polling to Padlets. Alone, we were adrift in a COVID sea of desperation. Together we were in a life raft helping save one another. Together, we gained confidence. Together, we got this!
One of the foundational principles that made our productivity possible was the concept of psychological trust. A champion of that concept is Amy Edmondson, a professor of leadership and management at Harvard University. This is her description from a recent article co-authored with Mark Mortenson in the Harvard Business Review (2021):

Psychological safety -the belief that one can speak up without risk of punishment or humiliation - has been well established as a critical driver of high-quality decision making, healthy group dynamics and interpersonal relationships, greater innovation, and more effective execution in organization. (p. 1)

While they write for the workplace, I would like to think of the classroom as our workplace, where students and teachers do important educational work. There is a growing interest in the phycological underpinnings that set us up for success.

\section{Create to learn for media literacy educators}

As our daily time together concluded in June 2020, it occurred to us the lessons learned would be valuable to others. When we stopped meeting every day, a small group of us decided that, as the new school year approached and some of us would still be teaching remotely, it became clear it would be crucial to share our newly minted knowledge with our colleagues. We brainstormed ways to share our lessons learned.

We built a website which we distributed, called Best Online Meetings (McDonough et al., 2020). Working collaboratively, we shared key ideas about navigating platforms, building a trusting community through emotional check-ins, representing your digital identity, facilitating meetings, and our favorite digital tools that make synchronous video meetings come alive. Word got back to us that it had even been translated into Portuguese by educators in Brazil, as they sought simple strategies to help their own online teaching efforts.

It all starts with connections. When you ask, "What do you know, and who wants to share something?" then we all do the work of contributing, connecting the dots, and making connections. That's not just true for adults; the kids in our classrooms can do this as well. I made it a priority to establish connections with my own students and this simple practice vastly improved my distance learning outcomes. VVH preserved my sanity in trying times, and made me a much better teacher. 


\section{REFERENCES}

Edmonson, A., \& Mortenson, M. (2021, April 19). What psychological safety looks like in a hybrid workplace. Harvard Business Review.

https://hbr.org/2021/04/what-psychological-safetylooks-like-in-a-hybrid-workplace

Goble, D. (2020). Media Makers.

https://www.dongoble.com/media-makers

McClanahan, L. (2020). Bellingham Quarantine. [Video] https://vimeo.com/409525264

McDonough, E. (2020). Cherish the Moments - 2020 Hindsight. [Video].

https://drive.google.com/file/d/10B1omjHFlZBYF YiONT_lzSAN_OWlEJPU/view

Zoom (1972). TVDB Photo Source. [PR Poster]. https://www.thetvdb.com/series/zoom 